\title{
KEDUDUKAN KEPALA NEGARA \\ DALAM SISTEM PEMERINTAHAN \\ ISLAM (Analisis Kritis terhadap Peran \\ Khalifah dalam Dustûr al-Islâmy \\ Hizbut Tahrir)
}

\author{
Robitul Firdaus \\ Fakultas Syariah Institut Agama Islam Negeri (IAIN) Jember | \\ robitfirdaus86@gmail.com \\ DOI: https://doi.org/10.35719/ijl.v1io1.72
}

\begin{abstract}
State leaders as leaders of government organizations have a strategic position in a state system. Hizbut Tahrir in the Draft Islamic Law (Dustûr al-Islâmy) which was first compiled by Taqiyuddin An-Nabhani even discoursed on great power in the hands of the head of state. A caliph (head of state) is not only dominant in the executive sector, but also has an important role in the legislative and judicial sectors as in the trias politica theory. This paper aims to critically analyze the role of the caliph in the Islamic government system as discoursed by Hizbut Tahrir. This is important because the regulation of the world of politics and the state cannot be solely based on the historical facts of Islamic civilization and ignores the development of the needs of the times and sociological factors. The rules regarding the caliphate contained in Dustûr al-Islâmi Hizbut Tahrir are still strongly influenced by the history of Islamic civilization at the time of the Prophet and Khulafâ' al-Rasyidn. The granting of enormous power to a khalfah is based on the assumption that the personal qualities of a caliph are on par with the Prophet and his chosen Companions. Of course this is not appropriate to be applied in today's era. Therefore, the power of the head of state must be limited and balanced. In this context, the offer of a modern democratic system through the mechanism of separation and division of power can be an offer to modify the
\end{abstract}


Hizbut Tahrir caliphate system to achieve the ideal goal of 'Islamic government'.

Keywords: Hizbut Tahrir, Khalîfah, Dustûr al-Islâmy

\begin{abstract}
Abstrak: Kepala negara sebagai pemimpin organisasi pemerintahan memiliki kedudukan yang strategis dalam sebuah sistem kenegaraan. Hizbut Tahrir dalam Rancangan Undang Undang Islam (Dustûr al-Islâmy) yang disusun pertama kali oleh Taqiyuddin An-Nabhani bahkan mewacanakan kekuasaan besar di tangan kepala negara. Seorang khalifah (kepala negara) tidak hanya dominan di sektor eksekutif, namun juga memiliki peran yang penting di sektor legislatif dan yudikatif sebagaimana teori trias politica. Tulisan ini bertujuan untuk menganalisa secara kritis peran khalifah dalam sistem pemerintahan Islam yang diwacanakan Hizbut Tahrir. Hal ini menjadi penting karena pengaturan dunia politik dan kenegaraan tidak dapat sematamata didasarkan atas fakta historis peradaban Islam dan mengabaikan perkembangan kebutuhan zaman dan faktor sosiologis. Aturan tentang khalifah yang terdapat dalam Dustûr al-Islâmi Hizbut Tahrir sangat tampak masih terpengaruh kuat dari sejarah peradaban Islam pada masa Rasulullah dan Khulafâ' al-Rasyidûn. Pemberian kekuasaan yang sangat besar kepada seorang khalîfah didasari atas asumsi kualitas personal seorang khalifah yang setara dengan Nabi dan para Sahabat pilihan. Tentu hal yang demikian kurang tepat untuk diterapkan pada era kini. Oleh karenanya, kekuasaan kepala negara harus dibatasi dan memiliki penyeimbang. Dalam konteks ini, tawaran sistem demokrasi modern melalui mekanisme pemisahan maupun pembagian kekuasaan dapat menjadi tawaran untuk memodifikasi sistem kekhalifahan Hizbut Tahrir untuk mencapai tujuan ideal 'pemerintahan Islam'.
\end{abstract}

Kata Kunci: Hizbut Tahrir, Khalîfah, Dustûr al-Islâmy

\title{
Pendahuluan
}

Runtuhnya kekhalifahan Islam pada tahun 1924 dari tangan Turki Utsmani di satu sisi menghapuskan sejarah khilâfah dalam Islam, sementara di sisi lain, justru 
menghadirkan sekian banyak tokoh dan kelompok yang berjuang untuk kembali menegakkan sejarah tersebut. Muhammad Rasyid Ridấ, Hasan al-Banâ, ${ }^{2}$ Taqiyuddin anNabhâni, ${ }^{3}$ dan beberapa tokoh lain misalnya adalah contoh para pemikir dan aktivis yang terlibat dan berdakwah aktif dalam usaha mengembalikan khilâfah Islam. Di level nasional, upaya mengembalikan sistem Islam sebagai sistem pemerintahan seolah bergema di beberapa negara berpenduduk Muslim. Salah satu kelompok atau gerakan transnasional yang secara konsisten mengkampanyekan dan mengupayakan ideologi tersebut adalah Hizbut Tahrir dimana hisbut tahrir mendefinisikan dirinya sebagai partai politik yang berideologi Islam, bercita-cita untuk melanjutkan kembali kehidupan Islam melalui tegaknya Daulah Islam yang akan menerapkan sistem Islam serta mengemban dakwah ke seluruh dunia. Dengan menjadikan beberapa wilayah sebagai benih berdirinya Daulah Islâmiyyah, diharapkan dakwah

\footnotetext{
${ }^{1}$ Dia adalah pendukung eksistensi Dinasti Utsmaniyah yang setia. Pemikiran dan aktivitas yang dilakukannya banyak yang bertujuan untuk tetap menjaga tetap tegaknya sistem khiläfah. Lebih lengkap tentang Rasyid Ridha dapat dibaca dalam Munawwir Syadzali, Islam and Govermental System; Teaching, History, and Reflections, (Jakarta: INIS, 1991), hal. 84-95.

${ }^{2}$ Ibid., hal. 100-108. Hasan al-Bana adalah pendiri Ikhwanul Muslimin. Meski tidak langsung merujuk pada pendirian khiläfah, namun pemikiran politik Ikhwanul Muslimin salah satunya adalah membentuk kekuasaan dunia Islam dalam satu kekuasaan politik, di bawah satu pemerintahan supra nasional, sama dengan konsep khilâfah. Tentang al-Bana juga bisa dibaca William Montgomery Watt, Fundamentalisme Islam dan Modernitas, terj. (Jakarta: PT RajaGrafindo, 1997), hal. 110-114.

3 Taqiyuddin an-Nabhâni adalah Pendiri Hizbut Tahrir sekaligus penyusun Rancangan Undang-Undang Dasar yang disiapkan untuk sistem khilâfah. yang digagasnya.
} 
Islam ke seluruh dunia dapat tercapai. ${ }^{4}$ Dalam upaya mewujudkan niat tersebut, Hizbut Tahrir telah mempersiapkan alat kelengkapan negara, berupa UndangUndang. Dalam karyanya yang dikeluarkan Hizbut Tahrir dengan judul al-Daulah al-Islâmiyyah dan versi Indonesianya diterbitkan HT Indonesia, Taqiyyuddin an-Nabhani menyusun Rancangan Undang-Undang Dasar Islam (Dustûr al-Islâmi). ${ }^{5}$

Salah satu isu penting dalam dialog sistem pemerintahan Islam adalah persoalan kepemimpinan negara. Pentingnya kepemimpinan bisa dilihat dari berbagai definisi kepemimpinan yang diberikan beberapa pakar. ${ }^{6}$ Meski sedikit berbeda dalam membahasakan, namun kepemimpinan secara umum bisa didefinisikan sebagai kemampuan seseorang untuk mempengaruhi, menggerakkan, dan mengarahkan tingkah laku orang lain atau kelompok untuk mencapai tujuan kelompok dalam situasi tertentu.

Dalam khazanah Islam, dikenal beberapa konsep yang

\footnotetext{
4 Taqiyuddin an- Nabhâni, Mafâhîm Hizbut Tahrir, terj. Abdullah, (Jakarta Selatan: Hizbut Tahrir Indonesia, 2001), hal. 21.

5 Taqiyuddin an- Nabhâni, al-Daulah al-Islâmiyyah, terj. Umar Faruq, dkk., (Jakarta: HTI Press, 2009), hal. 295-338.

6 Misalnya Ordway Tead mendefinisikan kepemimpinan adalah kegiatan mempengaruhi orang-orang agar mereka mau bekerja sama untuk mencapai tujuan yang diinginkan. George R. Terry mengartikan kepemimpinan sebagai kegiatan mempengaruhi orang-orang agar mereka suka berusaha mencapai tujuan-tujuan kelompok. Kimball Young mendefinisikan kepemimpinan dengan bentuk dominasi didasari kemauan pribadi yang sanggup mendorong atau mengajak orang lain unuk berbuat sesuatu, berdasarkan akseptasi atau penerimaan oleh kelompoknya dan memiliki keahlian khusus yang tepat bagi situasi khusus. baca Kartini Kartono, Pemimpin dan Kepemimpinan (Jakarta: PT. Raja Grafindo Persada, 1994), hal. 49-50.
}

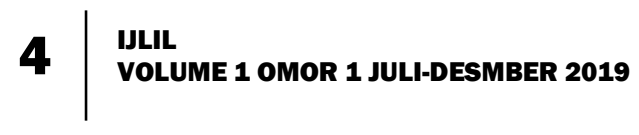


berkaitan dengan kepemimpinan negara, di antaranya yaitu: khilâfah, Imam, dan Ulil Amr. ${ }^{7}$ Secara etimologi atau kebahasaan ketiganya bisa dibedakan, namun dalam ranah terminologi sistem kekuasaan, ketiganya seringkali digunakan untuk tugas yang sama, yakni mengacu pada kekuasaan kepala negara Islam. Landasan normatif yang digunakan untuk melegitimasi model kepemimpinan ini umumnya mengacu pada al-Qurân Surat al-Nisâ' ayat 59, "Hai orangorang yang beriman, taatilah Allah dan taatilah Rasul (nya), dan ulil amri di antara kamu...". Hizbut Tahrir dalam menunjuk kepala negara Islam lebih sering menggunakan istilah khilâfah. Pilihan ini menurut penulis bukan saja faktor pilihan bahasa saja, namun lebih merupakan pilihan politis. ${ }^{8}$

Tulisan ini mengambil fokus pada aplikasi dari pemikiran tokoh Hizbut Tahrir yang telah diturunkan dengan content yang lebih riil dan dinilai aplikatif dalam format Dustûr al-Islâmi. Salah satu isu penting dalam konteks politik yang penulis pilih menjadi fokus dalam

\footnotetext{
${ }^{7}$ Hizbut Tahrir juga mengakui adanya beberapa gelar tersebut yang biasa disematkan kepada kepala Negara, lihat Hizbut Tahrir, Struktur Negara Khilafah (Pemerintahan dan Administrasi), terj. Yahya A.R., (Jakarta: HTI Press, 2008), hal. 32.

8 Saphir Whorf menemukan bahwa bahasa menentukan cara berpikir, dan cara berpikir pada gilirannya menentukan cara bersikap dan bertindak. Penggunaan bahasa sebagai alat menjaga kelangsungan sistem politik pernah diteliti, misalnya oleh Muray Edelman. Edelman mendapati fakta bahwa bahasa yang digunakan oleh elit politik di Amerika untuk mempertahankan sistem politik mereka setidaknya meliputi empat macam bahasa: (a) bahasa hukum (legalistic language), (b) bahasa yang bersifat membujuk atau menghimbau (hortatory language), (c) bahasa birokrasi (administrative language), dan (d) bahasa tawar menawar (bargaining language). Pawito, Komunikasi Politik; Media Massa dan Kampanye Pemilihan, (Yogyakarta: Jalasutra, 2009), hal. 32-33.
} 
tulisan ini adalah tentang peran khalifah sebagai kepala negara dalam sistem pemerintahan Islam versi Hizbut Tahrir. Lebih jelasnya lagi, penulis akan fokus pada dua hal. Pertama, mendeskripsikan peran dan wewenang dari Khalifah sebagaimana ditulis dalam Dustûr al-Islâmi. Kedua, melakukan analisa terhadap konsep tersebut dengan menggunakan perspektif fikih siyasah.

\section{Pembahasan}

\section{Sekilas tentang Pemikiran Hizbut Tahrir}

Meski Hizbut Tahrir bukanlah organisasi yang didasarkan pada ketokohan seseorang, namun kemunculannya tidak terlepas dari sosok kunci yang memiliki peranan besar. Taqiyuddin an-Nabhâni yang merupakan tokoh penting dalam kelahiran Hizbut Tahrir. Ideologi organisasi ini banyak dipengaruhi oleh pemikirannya. Ia berpandangan bahwa kaum muslimin berkewajiban untuk mendirikan partai politik yang berasaskan Islam.

Menurut Taqiyuddin, setidaknya ada tiga alasan di balik pentingnya melahirkan sebuah gerakan seperti Hizbut Tahrir. Pertama, Umat Islam telah mempelajari Islam dengan cara yang bertentangan dengan metode kajian yang telah digariskan Islam. Kedua, dunia Barat yang dengki dan membenci Islam dan kaum Muslim terus menerus menyerang agama Islam, baik penjajahan intelektual maupun wilayah. 
ketiga, banyaknya negeri-negeri Islam yang melepaskan diri lalu tunduk kepada pemerintahan kafir, ditambah dengan runtuh dan lenyapnya Daulah Islâmiyyah, maka terciptalah dalam benak kaum Muslim gambaran yang memustahilkan terwujudnya kembali Daulah Islâmiyyah berikut terlaksananya kembali hukum Islam sebagai satu-satunya hukum yang harus diterapkan. ${ }^{9}$ Politik dalam pandangan Hizbut Tahrir adalah pengaturan urusan umat di dalam dan luar negeri. ${ }^{10}$ Politik menurut Hizbut Tahrir dilaksanakan oleh negara dan umat, karena negaralah yang secara langsung melakukan pengaturan ini secara praktis, sedangkan umat mengawasi negara dalam pengaturan tersebut. ${ }^{11}$ Hizbut Tahrir mendefinisikan dirinya sebagai sebuah partai politik yang berideologi Islam. Hizbut Tahrir bergerak dan berjuang untuk mendirikan kembali sistem khilâfah. Hizbut Tahrir merupakan organisasi politik, bukan organisasi kerohanian (seperti tarekat), bukan lembaga ilmiah (seperti lembaga studi agama atau badan penelitian), bukan lembaga pendidikan (akademis), dan bukan pula lembaga sosial (yang bergerak di bidang sosial kemasyarakatan). ${ }^{12}$

Hizbut Tahrir mendefinisikan partai politik (hizbun

\footnotetext{
9 Taqiyuddin an-Nabhâni, Mafâhîm....., hal. 13-21.

1o Anonim, Afkâr Siyâsah (ttp: Hizbut Tahrir, 1994), hal. 5 .

"Taqiyuddin an-Nabhâni, Mafâhîm Siyâsah li Hizbit Tahrir, terj. M. Siddiq al-Jawi (Jakarta Selatan: Hizbut Tahrir Indonesia, 2007), hal. 7.

12 Taqiyuddin an-Nabhâni, al-Takatul al-Hizby, terj. Zakaria Labib, dkk (Jakarta Selatan: HTI Press, 2007), hal. 31.
} 
siyasi) sebagai suatu kelompok yang terorganisir yang anggota-anggotanya mempunyai orientasi, nilai-nilai, cita-cita dan tujuan yang sama dalam rangka mengurusi urusan rakyat. Dengan kata lain, partai politik adalah kelompok yang berdiri di atas sebuah landasan ideologi yang diyakini oleh anggotaanggotanya, yang ingin mewujudkannya di tengah masyarakat. ${ }^{13}$ Sedangkan partai politik Islam dalam pandangan mereka adalah partai yang berupaya menyadarkan masyarakat dan berjuang bersamanya untuk melanjutkan kehidupan Islam. Partai politik Islam tidak ditujukan untuk meraih suara dalam Pemilu atau berjuang meraih kepentingan sesaat, melainkan partai yang berjuang untuk merubah sistem sekular menjadi sistem yang diatur oleh syariat Islam. Orang-orang dan ikatan antara mereka hingga terorganisir menjadi satu kesatuan, serta orientasi, nilai, citacita, tujuan dan kebijaksanaan yang sama semuanya haruslah didasarkan dan bersumber dari Islam. ${ }^{14}$

Ada kaitan yang erat antara dakwah dan politik dalam pandangan Hizbut Tahrir. Perjuangan politik dilakukan demi mengemban dakwah Islam agar Islam dapat diterapkan dalam kehidupan dan agar 'aqidah Islâmiyyah menjadi dasar negara, dasar konstitusi dan undang-undang. Karena 'aqidah

\footnotetext{
${ }^{13}$ Ibid., hal. 53 .

14 Robitul Firdaus, "Pemisahan Kekuasaan dan Organisasi Negara dalam Sistem Pemerintahan Islam,” Tesis, (Yogyakarta: Pascasarjana UIN Sunan Kalijaga, 2010), hal. 69.
} 
Robitul Firdaus

Islâmiyyah menurut Hizbut Tahrir adalah 'aqidah 'aqliyah (akidah yang menjadi dasar pemikiran) dan 'aqidah siyasiyāh (akidah yang menjadi dasar politik) yang melahirkan aturan untuk memecahkan problematika manusia secara keseluruhan, baik di bidang politik, ekonomi, budaya, sosial, dan lain-lain. Sebuah partai politik ideologis menurut Hizbut Tahrir menetapkan metode perjalanan dakwahnya dalam 3 (tiga) tahapan yaitu ${ }^{15}$ tahapan pembinaan dan pengkaderan (marhalah al-tatsqif), yang dilaksanakan untuk membentuk kader-kader yang mempercayai pemikiran dan metode Hizbut Tahrir dalam rangka pembentukan kerangka tubuh partai, tahapan berinteraksi dengan umat (marhalah tafầul ma'a alummah), yang dilaksanakan agar umat turut memikul kewajiban dakwah Islam, hingga umat menjadikan Islam sebagai permasalahan utamanya, agar umat berjuang untuk mewujudkannya dalam realitas kehidupan dan tahapan penerimaan kekuasaan (marhalah istilâm al-hukm), yang dilaksanakan untuk menerapkan Islam secara menyeluruh dan mengemban risalah Islam ke seluruh dunia.

Hizbut Tahrir melakukan perjuangan pemikiran, menentang berbagai paham, pemikiran, dan ideologi yang menjadi landasan dan dikembangkan oleh ideologi sekularisme, baik yang bercorak kapitalistik maupun sosialistik. Hizbut Tahrir menentang dengan keras konsep-

\footnotetext{
15 Taqiyuddin an-Nabhâni, al-Takatul....., hal. 51-52.
}

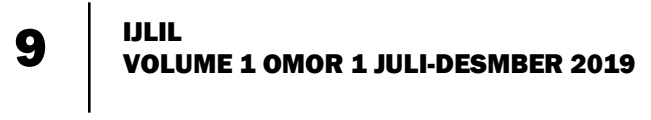


konsep yang lahir dari paham sekulerisme seperti demokrasi, patriotisme, sosialisme, dan kapitalisme atau isme-isme lain. ${ }^{16}$ Namun, Hizbut Tahrir tidak menggunakan aktivitas kekerasan (fisik) dalam perjuangannya. Menurut Hizbut Tahrir, dakwah itu tidak hanya harus bermain pada wilayah ritual dan akhlak saja, namun dakwah harus juga sangat politis. Artinya, dakwah juga berarti melakukan perjuangan politik untuk mencapai kekuasaan secara sempurna dalam rangka mewujudkan Daulah Islam. kehidupan Islam di negeri Islam dan mengembangkan dakwah Islam ke seluruh dunia menurut Hzibut Tahrir hanya bisa dilakukan melalui pemerintahan atau kekuasaan. ${ }^{17}$

\section{Pola Umum Dustûr al-Islâmy Hizbut Tahrir}

Setidaknya ada 15 Bab yang tertuang dalam klausul RUU Hizbut Tahrir atau dalam kitab aslinya disebut masyru' aldustur dan diterjemahkan oleh Hizbut Tahrir Indonesia dengan nama Rancangan UUD Islami (dustûr alIslâmi): ${ }^{18}$ antara lain Bab Hukum-Hukum Umum, Bab Sistem Pemerintahan, Bab khilâfah (kepala negara), Bab Mu'âwin atTafwîd (Wakil Khalifah Bidang Pemerintahan), Bab Mu'âwin

\footnotetext{
${ }^{16}$ Hizbut Tahrir beralasan bahwa dengan melaksanakan sistem-sistem tersebut berarti negara-negara Islam masih tunduk di bawah qiyâdah fikriyah (kepemimpinan berpikir) Barat yang demokrasi kapitalis dan itu juga berarti belum lepas dari penjajahan, lihat Taqiyuddin an-Nabhâni, Mafâhîm...... hal. 122.; Taqiyuddin anNabhâni, al-Takâtul, hal. 20-21.

${ }_{17}$ Taqiyuddin an-Nabhâni, Mafâhîm....., hal. 118-120.

${ }^{18}$ Taqiyuddin an- Nabhâni, Daulah Islam, terj. Umar Faruq dkk., (Jakarta: HTI-Press, 2009), hal. 295-338.
} 
Tanfiz (Pembantu Khalifah Bidang Kesekretariatan), Bab Amârul Jihâd, Bab Angkatan Bersenjata, Bab Peradilan, Bab Kewalian, Bab Aparat Administrasi, Bab Majelis Ummat, Bab Sistem Pergaulan Pria Wanita (An Nizâm al Ijtima’i), Bab Sistem Ekonomi, Bab Strategi Pendidikan dan Bab Politik Luar Negeri.

Aturan-aturan dalam bab-bab tersebut kemudian diturunkan menjadi beberapa pasal dan ayat yang lebih detail. Bila lebih diglobalkan, sebenarnya Dustûr al-Islâmi HT ini hanya terdiri dari enam bagian pokok. Pertama, ketentuan umum. Kedua, Sistem pemerintahan, Ketiga, Sistem pergaulan pria dan wanita. Keempat, Sistem Ekonomi, Kelima, Strategi pendidikan. Keenam, Politik luar negeri. Terlihat bahwa porsi terbesar yang menjadi prioritas dalam Dustûr al-Islâmi HT adalah sistem pemerintahan dengan penjelasan lebih rinci pada setiap bagiannya.

Ketentuan atau hukum-hukum umum yang dimaksud dalam Dustûr al-Islâmi Hizbut Tahrir sejenis kaedah-kaedah dasar yang menjadi penopang berdirinya Daulah Islam. Beberapa di antaranya diambil secara langsung dari qầidah usûl fiqh, ${ }^{19}$ sementara yang lain diambilkan dari hasil induksi ayat-ayat al-Qurân, Hadis, dan sejarah sahabat. Karena

\footnotetext{
${ }_{19}$ Lihat pasal 13 Dustûr al-Islâmy Hizbut Tahrir "Setiap manusia bebas dari tuduhan sampai terbukti kesalahannya” (al ashlu bara'atu adz-dzimah). Pasal 14 Dustûr alIslâmy Hizbut Tahrir "Hukum asal bagi setiap benda/alat yang digunakan hukumnya mubah, selama tidak terdapat dalil yang mengharamkannya” (al ashlu fiy al asy-yâ' $i$ al ibahâh mâ lam yarid daliilu at tahriim)
} 
sifatnya yang demikian, maka susunan antar pasal dalam bab ini tidaklah sistematis. Belum tercipta koherensi antar pasalpasalnya. Terdapat 15 pasal yang tertuang dalam bab ini. Secara umum dapat penulis klasifikasikan menjadi 6 bagian yaitu: Pasal 1 dan 2 menjelaskan tentang dasar negara dan definisi Daulah Islam, Pasal 3 dan 4 tentang kekuasaan legislasi Khalîfah, Pasal 5, 6, 7, 9, dan 13 berbicara tentang hak-hak warga negara dalam Daulah Islam, Pasal 8 tentang bahasa arab sebagai bahasa negara, Pasal 10 dan 11 tentang kewajiban warga negara dan negara dan Pasal 9, 12, 14, dan 15 menjelaskan tentang aturan ijtihad dalam Daulah Islam.

Berikutnya adalah bab tentang sistem pemerintahan. Bab ini menjelaskan mengenai aturan pokok dalam negara Islam versi HT, seperti menganut sistem negara kesatuan, pemerintahan sentralisasi, kedaulatan Tuhan meski kekuasaan di tangan umat, dan struktur aparatur negara yang terdiri dari delapan bagian dan selanjutnya diturunkan dalam masing-masing bab tersendiri.

Yang menarik dalam RUU ini juga tercantum bab khusus yang tentang sistem pergaulan pria dan wanita. Bab ini terdiri dari 11 pasal yang mengatur pola hubungan antara laki-laki dan perempuan. Lebih tepatnya menurut penulis, pasal-pasal tersebut mengatur peran perempuan di ranah 
publik maupun privat. $^{20}$ Pengaturan tersebut juga amat terkait dengan apa yang boleh dan tidak boleh dilakukan atau pembatasan peran perempuan di berbagai sektor kehidupan, mulai dari keluarga, ${ }^{21}$ ekonomi, ${ }^{22}$ hingga politik. ${ }^{23}$

Selain muatan pasal-pasal pada bab ini masih dapat diperdebatkan dan dikritisi, pencantuman pengaturan hal-hal semacam ini dalam sebuah undang-undang dasar menurut penulis tidak begitu tepat, karena sifatnya yang sudah sangat praktis. Kalaupun terpaksa harus dicantumkan, seharusnya hanya norma-norma umum saja dan dikumpulkan dengan bagian ketentuan atau hukum-hukum umum, tanpa dibuat dalam bab tersendiri. ${ }^{24}$

Muatan selanjutnya dari Rancangan Undang-Undang negara Islam yang diikuti Hizbut Tahrir dan terdapat dalam kitab Nizâmul Islâm adalah bab sistem ekonomi. Terhitung sebanyak 46 pasal yang termuat dalam aturan tentang sistem ekonomi ini. Aturan-aturan tersebut berkisar dalam banyak hal, di antaranya tentang jenis hak milik, ${ }^{25}$ sumber pemasukan

\footnotetext{
${ }^{20}$ Lihat dalam pasal 113, 114, dan 115 Dustûr al-Islâmy Hizbut Tahrir.

${ }^{21}$ Lihat dalam pasal 108, 116, 117, dan 118 Dustûr al-Islâmy Hizbut Tahrir.

${ }^{22}$ Lihat dalam pasal 109 dan 110 Dustûr al-Islâmy Hizbut Tahrir.

${ }^{23}$ Lihat dalam pasal 111 dan 112 Dustûr al-Islâmy Hizbut Tahrir.

${ }^{24}$ Oleh karenanya menurut Ibnu Sina, sebuah undang-undang dasar tidak boleh terlalu mencampuri persoalan-persoalan yang tidak perinsipil, kerena dia akan berkembang dan berubah menurut perubahan masa dan harus diserahkan kepada majelis musyawarah, Zainal Abidin Ahmad, Negara Negara Islam, (Jakarta: Penerbit Wijaya, 1956), hal. 282.

25 Kepemilikan dalam RUU ini dibagi dalam tiga jenis: kepemilikan individu, kepemilikan umum dan kepemilikan negara. Detail pembagian ini diatur dalam pasal 122 sampai dengan pasal 137 .
} 
negara (fai', jizyah, kharaj, seperlima harta rikâz atau temuan dan zakat), ${ }^{26}$ fungsi dan peran Baitul Mâl, ${ }^{27}$ hak ekonomi masyarakat, ${ }^{28}$ dan sistem pertukaran mata uang. ${ }^{29}$

Bab mengenai strategi pendidikan mencantumkan enam pasal. Keenam pasal tersebut banyak berbicara tentang model pendidikan di dalam negara Islam, seperti tujuan pendidikan, kurikulum sekolah, dan fasilitas pendidikan. Pada pasal terakhir dari bab ini juga menyinggung mengenai tidak adanya hak royalti bagi pengarang buku yang bukunya telah diterbitkan. Itu artinya penolakan Hizbut Tahrir terhadap sistem hak cipta (copyright).

Bagian terakhir dalam RUU ini adalah tentang politik luar negeri. Terdapat 11 pasal dalam bab ini yang mengatur kebijakan-kebijakan dasar politik luar negeri negara Islam. Salah satu bagian terpenting dalam bab ini adalah mengenai pembagian empat pola hubungan luar negeri negara Islam: ${ }^{30}$

1. Negara-negara yang ada di dunia Islam seolah-olah dianggap berada dalam satu wilayah negara, sehingga tidak dikategorikan dalam hubungan luar negeri dan tidak dimasukkan dalam politik luar negeri. Negara berkewajiban menggabungkan negara-negara tersebut

\footnotetext{
${ }^{26}$ Pasal 139 sampai dengan pasal 142 dan pasal 145 Dustûr al-Islâmy Hizbut Tahrir.

${ }_{27}$ Pasal 146 sampai dengan pasal 148 Dustûr al-Islâmy Hizbut Tahrir.

${ }_{28}$ Pasal 121, Pasal 149 sampai dengan pasal 154, dan pasal 16o Dustûr al-Islâmy Hizbut Tahrir.

${ }^{29}$ Pasal 162 sampai dengan pasal 164 Dustûr al-Islâmy Hizbut Tahrir.

3o Pasal 184 ayat (1), ayat (2), ayat (3), dan ayat (4) Dustûr al-Islâmy Hizbut Tahrir.î
} 
ke dalam wilayahnya.

2. Negara-negara yang terikat perjanjian di bidang ekonomi, perdagangan, bertetangga baik atau perjanjian kebudayaan dengan negara khilâfah, maka negaranegara tersebut diperlakukan sesuai dengan isi teks perjanjian. Hubungan ekonomi dan perdagangan dengan negara-negara tersebut terbatas pada barang dan kondisi tertentu yang amat dibutuhkan, serta tidak menyebabkan kuatnya negara yang bersangkutan.

3. Negara-negara yang tidak terikat perjanjian dengan khâlifah termasuk negara-negara imperialis seperti Inggris, Amerika, dan Perancis begitu pula negaranegara yang memiliki ambisi pada negeri-negeri Islam seperti Rusia, maka secara hukum (de jure) dianggap negara yang memusuhi atau memerangi (muhâriban hukman). Negara menempuh berbagai tindakan kewaspadaan terhadap mereka dan tidak boleh menjalin hubungan diplomatik apapun. Penduduk negara-negara tersebut dibolehkan memasuki negeri-negeri Islam tetapi harus menggunakan pasport dan visa khusus bagi setiap individu untuk setiap kali perjalanan.

4. Negara-negara yang secara riil (de facto) berkonfrontasi, seperti Israel, maka terhadap negara tersebut harus diberlakukan sikap dalam keadaan darurat perang 
sebagai dasar setiap perlakuan dan tindakan, seolaholah khilâfah dan negara yang bersangkutan benarbenar dalam situasi perang, baik terdapat gencatan senjata ataupun tidak. Dan seluruh penduduknya dilarang memasuki wilayah Islam.

\section{Khalifah dalam Dustûr al-Islâmy}

Struktur pemerintahan yang diatur dalam Dustûr alIslâmi Hizbut Tahrir secara global terdiri dari sembilan bagian: Khalîfah (Kepala Negara), Mu'âwin Tafwîd (Wakil Khalīfah Bidang Pemerintahan), Mu'âwin Tanfiz (Pembantu Kepala Negara Bidang Kesekretariatan), Amîrul Jihâd, Angkatan Bersenjata, Al-Qadâ (peradilan), Al-Wulât (perwalian), Masâlihud Daulah (Aparat Administrasi) dan Majelis Umat.

Bila mengacu pada kitab yang dirujuk oleh anggota Hizbut Tahrir atau mereka istilahkan dengan "kitâb mutabannat" (adopted book), maka rujukan pertama saat membahas struktur negara Islam adalah kitab ad-Daulah alIslâmiyyah (2002), karya Taqiyuddin an-Nabhāni dan kitab Nizâm al-Hukm fial-Islâm (2002), karya Abdul Qadim Zallum. Pada kitab pertama terdapat dan tercantum rancangan undang-undang negara Islam (Dustûr al-Islâmy) Hizbut Tahrir. Kitab kedua adalah kitab penjelas dari kitab 
sebelumnya. Sembilan bagian yang telah disebutkan di atas adalah struktur negara versi dua kitab tersebut.

Sedangkan kitab terbaru yang diadopsi oleh Hizbut Tahrir, termasuk di Indonesia adalah kitab Ajhizah Daulah alKhilâfah fi al-Hukm wa al-Idârah yang versi indonesianya diterjemahkan dengan judul "Struktur Negara Khilâfah dalam Pemerintahan dan Administrasi” (2005). Kitab ini didudukkan sebagai kitab penyempurna dari kitab-kitab sebelumnya. ${ }^{31}$ Bentuk awal struktur negara yang telah disusun an-Nabhâni dalam kitab sebelumnya pada dasarnya sama sekali tidak mengalami perubahan. Hanya terjadi beberapa perincian dari apa yang telah dirumuskan sebelumnya.

Hal yang paling menonjol dari penyempurnaan kitab acuan Hizbut Tahrir ini adalah penambahan jumlah struktur dalam negara khilâfah menjadi 13 (tiga belas) bagian, yaitu: Khalîfah, Para Mu'âwin (Wuzârat at-Tafwîd), para pembantu Khalîfah dalam bidang pemerintahan, Wuzârat at-Tanfiz, para pembantu Khalīfah dalam bidang administrasi, Para Wāli (Gubernur), Amîrul Jihâd, Departeman Keamanan Dalam Negeri, Departemen Luar Negeri, Departemen Industri, Peradilan, Departemen-Departemen Negara untuk Pelayanan Masyarakat (Aparat administrasi), Baitul Mâl (Kas Negara), Departemen Penerangan dan Majelis Umat.

\footnotetext{
${ }^{31}$ Sebagaimana ditulis pada bagian depan kitab ini, wa huwa yulghi mâ khâlafahu (kitab ini membatalkan kitab sebelumnya yang menyalahinya).
} 
Dengan memahami peran, fungsi, atau wewenang dari masing-masing lembaga yang ada dalam negara khilâfah, maka bisa diidentifikasi bentuk dan sistem pemerintahan ala Hizbut Tahrir. Sesuai dengan namanya, sistem negara khilâfah memberikan porsi wewenang yang sedemikian besar terhadap Khalîfah. Meski tidak sepenuhnya seperti Nabi yang berkuasa penuh di tiga bidang kekuasaan; eksekutif, legislatif, dan yudikatif, namun hampir bisa dikatakan bahwa dengan wewenang yang demikian besar, Khalîfah dalam model pemerintahan Hizbut Tahrir juga memiliki wewenang di ketiga bidang tersebut.

Khalîfah berwenang menjalankan pemerintahan (eksekutif), membuat dan melegislasi undang-undang (legislatif), serta mengangkat dan memberhentikan hakim, serta hakim bertanggung jawab kepada Khalîfah (yudikatif). ${ }^{32}$ Meski ada Majelis Umat sebagai penyeimbang dalam bidang legislatif dan Qâdi Mazalim dalam bidang yudikatif, namun kedudukannya tidaklah berimbang. Kedua lembaga tersebut bisa dikatakan masih berada dan menjadi subordinat Khalîfah.

Majelis Umat hanya menjadi semacam lembaga penasehat Khalîfah yang tidak memiliki hak kontrol kuat. Keputusan Majelis yang dijalankan dengan musyawarah tidak

\footnotetext{
${ }^{32}$ Hizbut Tahrir, Struktur....., hal. 64.
} 
semuanya bersifat mengikat. Hanya persoalan non-strategis ${ }^{33}$ yang mengikat, sementara dalam hal strategis, Khalîfah memiliki hak preogratif ${ }^{34}$ yang boleh tidak mengindahkan hasil musyawarah Majelis Umat. Lembaga ini juga tidak memiliki hak melegislasi hukum. Khalîfah tidak berkewajiban meminta hukum yang akan diadopsi untuk dimusyawarahkan Majelis Umat. Musyawarah Majelis Umat dalam rangka penetapan undang-undang adalah hak Khalifah yang boleh diambil atau tidak. Kalaupun Khalîfah melakukannya, keputusan Majelis Umat tidaklah mengikat Khalîfah. ${ }^{35}$

Sementara peradilan ( qadhâ') sebagai pelaksana bidang yudikatif juga tidak terlalu banyak berbeda. Hanya saja dalam konteks check and balances, pengaturan bidang yudikatif ini masih lebih baik daripada bidang legislasi. Dalam sistem yudikatif, Khalîfah menentukan satu orang pemimpin peradilan (Qâdhi al-Qudhât atau Amîr Qadhâ') yang memiliki wewenang mengangkat qâdhi-qâdhi, memperingatkan, dan memberhentikan mereka dari jabatannya. ${ }^{36}$ Namun, hak tersebut adalah hak dalam kapasitasnya mewakili Khaliffah bukan dalam kapasitas sebagai pemimpin lembaga yudikatif

\footnotetext{
33 Yang masuk dalam kategori ini adalah seperti urusan ketatanegaraan, pendidikan, kesehatan, ekonomi, perdagangan, industri, pertanian dan lain-lain, Pasal 107 ayat 1a Dustûr al-Islâmy Hizbut Tahrir.

34 Yang masuk dalam kategori ini adalah seperti perkara-perkara keilmuan, keuangan, militer dan politik luar negeri, Pasal 107 ayat 1b Dustûr al-Islâmy Hizbut Tahrir.

35 Pasal 107 ayat 2 Dustûr al-Islâmy Hizbut Tahrir.

${ }^{36}$ Pasal 67 Dustûr al-Islâmy Hizbut Tahrir.
} 
yang berdiri sendiri. ${ }^{37}$ Yang dimaksud dengan lebih baik adalah bahwa bidang yudikatif telah berdiri sebagai sebuah lembaga, tidak include dalam diri Khalîfah, meski sebenarnya masih tetap berada di bawah bayang-bayang Khalîfah .

Hizbut Tahrir dalam rancangan undang-undang ini sebenarnya hanya menempatkan Kekuasaan berada di tangan empat pihak, yaitu Khalîfah, Mu'âwin Tafwîd, Wâli, dan 'Âmil. Selain mereka, tidak dianggap sebagai penguasa, melainkan hanya pegawai pemerintah. Khalîfah adalah pimpinan tertinggi dari semua lembaga negara. Hizbut Tahrir melakukan pembedaan antara kekuasaan (al-hukm, assulthân) dengan administrasi (al-idârah). Penguasa (alhâkim) adalah orang yang menjalankan kekuasaan atau pemerintahan (munaffidzul hukm), yang berwenang untuk menerapkan peraturan dan undang-undang atas rakyat. Dalam struktur negara Khilâfah, mereka yang memiliki kewenangan ini adalah empat pihak tadi. Selain mereka, tidak termasuk penguasa tetapi termasuk pegawai pemerintah (almuwazzaf) yang tugasnya berkaitan dengan administrasi, bukan kekuasaan. Administrasi (al-idârah) merupakan kumpulan cara yang bersifat teknis (uslûb) atau sarana fisik (wasîlah) untuk melaksanakan suatu aktivitas tertentu. ${ }^{38}$

\section{Analisis Kritis}

\footnotetext{
${ }^{37}$ Hizbut Tahrir, Struktur....., hal. 190.

${ }^{8}$ Pasal 18 Dustûr al-Islâmy Hizbut Tahrir.
} 
Acuan yang digunakan sistem khilafah versi Hisbut Tahrir banyak mengacu pada era Rasulullah Saw. atau Khulafâ' ar-Rasyîdûn dengan mengandalkan kualitas personal pemimpin Negara yang handal. Kalau pada era Rasulullah Saw. ketiga jenis kekuasaan politik berada di tangannya dan para Sahabat yang mampu diberi limpahan wewenang, maka penerapan sistem pemerintahan Hizbut Tahrir juga sedikit banyak mengikuti hal tersebut. Meski telah ada modifikasi pelimpahan kekuasaan yudikatif secara institusional kepada lembaga yudikatif, Majelis Qadhâ', namun sifatnya masih sangat parsial dan puncak pimpinan lembaga yudikatif juga masih berada di tangan Khalîfah .

Padahal mengingat kualitas kepemimpinan dan masyarakat yang berbeda, modifikasi dalam bentuk yang lebih luas mutlak diperlukan. Modifikasi tersebut sangat memungkinkan karena pemerintahan yang dilaksanakan Rasulullah Saw. dan Khulafâ' ar-Rasyîdûn sebenarnya tidaklah kaku. Pelimpahan kekuasaan yudikatif secara parsial tidak lagi bisa dipertahankan di era modern. Pelimpahannya harus secara keseluruhan untuk menjaga independensi dan kebebasan Majelis Qadâ' dalam menyelenggarakan tugastugasnya. Meskipun pada akhirnya, sesuai dengan prinsip delegasi, ketua majelis wajib mempertanggungjawabkan kekuasaan yang diamanatkan kepadanya.

Begitu pula modifikasi diperlukan berkenaan dengan 
kedudukan dan peran Khalîfah dalam legislasi. Kedudukan Rasulullah sebagai kepala lembaga legislatif tidak lagi bisa dipertahankan, sekali lagi karena kualitas kepemimpinan dan masyarakat yang berbeda. Struktur demikian justru dapat melahirkan pemerintahan yang otoriter dan tirani. Oleh karena itu, diperlukan modifikasi peran Khalîfah dalam legislasi. Dalam hal ini, berdasarkan konstitusi, kedudukan Khalîfah sebagai pimpinan lembaga legislatif, menurut Abdul Muin Salim, bisa dilimpahkan kepada tokoh lain. Selanjutnya Khaliffah dan lembaga legislatif bermusyawarah membuat undang-undang. Dengan struktur seperti ini, peran legislasi Khalifah tetap ada dan tindakan otoriter dapat dihindari. ${ }^{39}$

Maududi juga mengakui bahwa kalau mengacu pada sistem era Rasul dan Khulafầ' ar-Rasyîdûn, Khalīfah tidak terikat dengan lembaga legislatif semacam Majelis Umat. Meskipun prinsip musyawarah tetap berjalan di antara keduanya, namun Khalîfah memiliki hak veto berdasarkan apa yang diyakininya. Sistem seperti ini akan berjalan cukup baik dan tidak bermasalah saat karakter pemimpin dan orangorang yang duduk di lembaga musyawarah sama seperti era Rasul dan Khulafầ ar-Rasyîdûn. Namun menurut Maududi, selama negara belum berhasil membentuk karakter seperti itu, tidak ada alternatif lain selain membatasi dan

39 Abdul Muin Salim, Fiqh Siyasah; Konsepsi Kekuasaan Politik dalam Al-Qurân, (Jakarta: PT RajaGrafindo Persada, 2002), hal. 296-297. 
menundukkan lembaga eksekutif kepada keputusan mayoritas lembaga legislatif. $4^{\circ}$

Dalam konteks ini, maka peran Majelis Umat harus lebih diperkuat sebagai representasi rakyat, karena kedudukan rakyat sebagai subyek politik menuntut adanya tokoh-tokoh representatif untuk menyelenggarakan fungsifungsi politik, khususnya yang berkenaan dengan fungsi legislatif, sehingga aspirasi dan kepentingan kelompok dapat terakomodasi. Representasi rakyat harusnya memiliki peran yang cukup besar dalam hal legislasi undang-undang, Majelis Umat idealnya memiliki kedudukan yang sejajar dengan Khalîfah dalam proses legislasi atau bahkan menjadi lembaga yang bertanggung jawab penuh terhadap proses legislasi.

Sedangkan pada sisi lain, kedudukan rakyat sebagai obyek politik menuntut adanya tokoh-tokoh representatif yang akan melaksanakan pengawasan terhadap kegiatankegiatan politik dan pemerintahan. Untuk kepentingan yang terakhir ini, Majelis Umat yang di samping dapat mewakili rakyat untuk mengangkat dan mem-bai'at kepala negara, juga aktif mengawasi pemerintahan. Bahkan lebih lanjut, Majelis Umat, menurut Abdul Muin Salim, juga dapat menuntut pertanggung jawaban atau bahkan memakzulkan kepala

\footnotetext{
4o Abul A'la al-Maududi, Hukum dan Konstitusi Sistem Politik Islam, terj. Asep Hikmat (Bandung: Mizan, 1990), hal. 254. Oleh karenanya, al-Maududi berpendapat bahwa persoalan legislatif dalam Islam merupakan tugas yang dibebankan kepada ulama, baca M. Hasbi Amîruddin, Konsep Negara Islam Menurut Fazlur Rahman, (Yogyakarta: UII Press, 200o), hal.133.
} 
negara jika ia melakukan kesalahan yang termasuk dalam kategori "kekafiran yang nyata"41. Artinya, dua peran penting dari Majelis Umat yang penting untuk diperkuat adalah peran legislasi dan pengawasan.

Secara teoritis, Majelis Umat adalah lembaga paling ideal untuk menjadi proyeksi dari konsep Ahlul Halli wal 'Aqdi. Dalam beragam referensi politik Islam, lembaga semacam ini sebenarnya diberi kewenangan yang cukup besar sebagai penyeimbang Khalîfah Lembaga ini diberi kekuasaan untuk memilih Khalîfah ,mengawasi segenap perangkat undang-undang yang diciptakan, dan bahkan termasuk untuk menurunkan Khalîfah. Oleh karenanya, majelis semacam ini tidak semua orang bisa duduk di dalamnya. Ada kualifikasi tertentu yang harus dipenuhi. ${ }^{42}$ Bila dinisbahkan kepada fungsi lembaga legislatif, maka setidaknya ada tiga fungsi penting lembaga ini; fungsi legislasi, kontrol, dan perwakilan.

Fungsi pengawasan dalam negara Khilâfah dipegang oleh Mahkamah Mazalim melalui Qâdhi Mazalim. Hanya saja, lembaga ini pun masih jauh dari kata kuat sebagai penyeimbang ekskutif. Pasalnya, orang-orang yang duduk

\footnotetext{
${ }^{41}$ Abdul Muin Salim, Fiqh,....., hal. 293.

${ }^{42}$ Al-Mawardi misalnya menyebutkan tiga syarat: adil, berpengetahuan tentang yang berhak menjadi Khaliffah, dan rasional serta bijak, Al-Mawardi, al-Ahkâm alSultoniyyah wa al-Wilayat al-Diniyah (Beirut: Dar al-Kutub al-Ilmiyah, tt.), hal. 6. Tentang penjelasan ini juga bisa dibaca dalam Muhammad Bin Syakir Syarif, Muqaddimah fi Fiqh al-Nizâmi al-Islâmy (ttp: tp, tt), hal. 26.
} 
dalam lembaga ini juga ditunjuk oleh Khalîfah. ${ }^{43}$ Itu artinya, ada kemungkinan besar terjadinya konspirasi di tingkatan atas untuk mengamankan posisi Khilâfah Kemungkinan ini terkait dengan ketentuan lain bahwa kepemimpinan (jabatan) Khaliffah tidak mempunyai masa tertentu yang dibatasi dengan patokan waktu tertentu. Selama Khaliffah masih tetap menjaga syarîah, menerapkan hukum-hukumnya, serta mampu untuk melaksanakan berbagai urusan negara dan tanggung jawab kekhalifahan, maka ia tetap sah menjadi Khalîfah. ${ }^{44}$ Untuk mengantisipasi hal ini, Hizbut Tahrir hanya memberikan batasan pada Khalîfah dalam hal pencopotan Qâdi Mazalim, tapi membebaskan Khalîfah dalam pengangkatannya. 45

Padahal di sisi lain, Khalîfah pula yang berhak untuk memahami syara' dan melegislasi hukum. ${ }^{46}$ Akibatnya, tanpa ada kekuasaan yang mampu menandingi institusi Khalîfah, maka baik atau buruknya sistem yang berjalan tergantung pada baik dan buruknya Khaliffah yang memimpin. Itu artinya sistem ini sangat bergantung pada kapasitas personal

\footnotetext{
43 Bagian ini termasuk dalam kewenangan Khaliffah sebagaimana telah dijelaskan sebelumnya, lihat Hizbut Tahrir, Struktur....., hal. 63-64.

${ }^{44}$ Pasal 38 Dustûr al-Islâmy Hizbut Tahrir.

45 Dengan menggunakan kaidah Al-Wasīlah ilâ al-harâm harâmun (Sarana yang mengantarkan pada sesuatu yang haram adalah haram), maka Hizbut Tahrir membatasi pelarangan hak pencopotan Qâdi Mazalim, jika ia sedang menangani kasus yang berkenaan dengan Khalîfah. Dalam konteks selain itu, maka Khalîfah masih memilih hak mencopot atau menggantinya, lihat Hizbut Tahrir, Struktur....., hal. 203.

${ }^{46}$ Pasal 35 dan 36 Dustûr al-Islâmy Hizbut Tahrir.
} 
pemimpin dan sedikit mengabaikan substansi sistem yang berjalan. Kata-kata syara' yang berulang kali disebutkan sebagai jaminan institusi terkuat dan pencegah terjadinya penyelewengan juga tidak serta merta dapat berjalan. Pasalnya syara' itu sendiri belum berdiri sebagai sistem yang detail dan mandiri karena selalu terikat dengan bagaimana ia dipahami, semisal Nabhâni dalam memahami syara' tentang Khalîfah ini. ${ }^{47}$

Maududi, sebagaimana sarannya dalam kekuasaan legislatif, juga memberikan pendapat yang serupa dalam pelaksanaan kekuasaan yudikatif. Oleh karena cukup sulit mencari kepala negara yang standar ruhaniyah-nya sekaliber khulafầ ar-rasyîdûn, menurutnya dapat dipertimbangkan untuk membatasi kekuasaan-kekuasaan adminstratif kepala negara untuk tetap melindungi diri dari kediktatoran. ${ }^{48}$

Kekuasaan dan kontrol Khalîfah dalam ranah eksekutif juga terlihat dari dibentuknya Departemen Penerangan untuk mengendalikan informasi yang tersebar di tengah masyarakat. Dalam konteks yang berhubungan dengan rahasia negara,

\footnotetext{
47 Diakui atau tidak, Nabhani menjadi tokoh utama dalam pemikiran Hizbut Tahrir. Semua pemikirannya dianut dan diunggulkan daripada pemikiran ulama lain. Sebut saja misalnya dalam hal usûl fiqh. Hizbut Tahrir mengklaim menggunakan kinerja usûl fiqh ala Nabhâni yang terdapat dalam buku "Syakhsiyyah Islam". Padahal rumusan Nabhani yang terdapat buku tersebut -dalam pandangan penulis- masih jauh dari sangat sempurna bila kita meletakkan usûl fiqh sebagai satu disiplin ilmu. Lihat Taqiyuddin an-Nabhāni, al-Syakhsiyyah al-Islâmiyyah (Beirut: Darul Ummat, 2005). usûl fiqh ala Syafi'i dinilai terlalu berorientasi mazhab. Hizbut Tahrir mengambil Nabhâni dan menginginkannya menjadi usûl fiqh bagi semua mazhab.

$4^{8}$ Abul A'la al-Maududi, Hukum dan Konstitusi Sistem Politik Islam, terj. Asep Hikmat, (Bandung: Mizan, 1990), hal. 250.
} 
misalnya dalam bidang kemiliteran, aturan semacam ini wajar untuk diterapkan demi keamanan negara. Namun, dalam hal pembatasan media massa dan individu dalam menyebarkan berita atau pemikirannya, maka aturan tersebut bisa jadi mendatangkan problem baru. Bagaimanapun juga media massa ikut memainkan peran politik tersendiri dalam konteks kenegaraan. ${ }^{49}$

Meski dalam rumusannya disebutkan bahwa berita atau pemikiran yang akan dilarang adalah yang bertentangan dengan syarî̀ah. ${ }^{\circ}$ Namun, dalam prakteknya sudah pasti tidak sesederhana itu. Tafsir yang akan berlaku dalam memutuskan kesesuaian syarîah adalah tafsir penguasa. Artinya, tolak ukur yang juga digunakan adalah apa yang menguntungkan, netral, atau membahayakan penguasa. Fenomena semacam ini dalam bahasa Khaled M. Abou El Fadl disebut sebagai otoritarianisme (tafsir) Agama..$^{51}$

Dalam bahasa M. Adhiatera, otoritarianisme bisa melahirkan apa yang disebut sebagai religious totalitarianism dengan ciri-ciri antara lain sebagai berikut: Pertama, otoritas suatu rezim didasarkan atas mandat suci (holy mandate) dari Tuhan, sehingga masyarakat luas tidak boleh

\footnotetext{
49 Curan menyebutkan setidaknya terdapat tiga fungsi pokok media massa; fungsi informasi, fungsi representasi, dan fungsi membantu mencapai tujuan bersama masyarakat. Ketiganya penting dalam proses demokratisasi, lihat Pawito, Komunikasi....., hal. 102.

$5^{\circ}$ Hizbut Tahrir, Struktur....., hal. 246.

${ }^{51}$ Khaled M. Aboe El Fadl, Atas Nama Tuhan Dari Fikih Otoriter Ke Fikih Otoritatif, (Jakarta: Serambi, 2004), hal. 61.
} 
mempertanyakan legitimasinya karena ia berasal dari Tuhan. Ciri kedua, rezim itu akan memaksakan ajaran agama secara ketat dan mengontrol cara rakyat mengamalkan agamanya. Ini semua akan memberi peluang bagi penyalahgunaan kekuasaan oleh orang-orang yang menduduki kekuasaan. ${ }^{52}$ Atas dasar itulah, modifikasi tugas, wewenang, atau hubungan antar berbagai lembaga negara mutlak diperlukan.

\section{Kesimpulan}

Dustûr al-Islâmi Hizbut Tahrir memberikan wewenang yang lebih besar kepada seorang kepala Negara (Khalîfah). Khaliffah sebagai kepala negara dalam pemerintahan Hizbut Tahrir memiliki kuasa pembuatan undang-undang (legislasi) yang cukup kuat. Hasil ijtihad Khalîfah menentukan hukum syarīah mana yang akan diadopsi untuk menjadi UndangUndang. ${ }^{53}$ Hubungan antara Khalîfah dan Majelis Umat dalam struktur pemerintahan Hizbut Tahrir tidak pada posisi yang sejajar atau seimbang. Majelis Umat juga tidak berada di bawah kendali Khaliffah. Hubungan Majelis Umat dengan Khalīfah hanya terjadi pada dua hal; "membantu” Khalîfah dalam bidang legislasi ${ }^{54}$ dan memiliki hak kontrol terhadap

\footnotetext{
${ }^{52}$ Lihat M. Adhiatera, "Interfaith dialog: Agre to disagree" dalam The Jakarta Post, Mei 2, 2006.

53 Pasal 36 Dustûr al-Islâmy Hizbut Tahrir.

54 Pasal 107 ayat (1a), (1b), dan (2) Dustûr al-Islâmy Hizbut Tahrir.
} 
pejabat eksekutif di bawah Khalîfah.55 Namun, posisi Khalîfah dalam bidang legislasi lebih tinggi dari pada Majelis Umat. Khalîfah hanya terikat dalam legislasi terkait hal-hal yang tidak urgen dalam negara, sementara dalam hal yang urgen, Khalîfah tidak bisa diintervensi dan memiliki hak preogatif untuk mengambil keputusan. Sementara itu, lembaga peradilan menurut Hizbut Tahrir adalah lembaga yang menjadi wakil menjalankan tugas Khalîfah. Artinya, meski dalam kelembagaan tersendiri, namun kekuasaan yang dimiliki oleh peradilan tidak didasarkan pada kedudukannya sebagai lembaga yudikatif murni, namun merupakan perluasan dari tugas Khalîfah atau bagian dari eksekutif.

Sistem semacam ini tampak sangat bergantung pada kualitas personal kepemimpinan negara (Khalîfah). Padahal dalam ilmu politik modern, Kekuasaan ${ }^{56}$ yang sedemikian besar sangat tidak efektif bila berada di satu tangan lembaga. Sebagaimana disebutkan dalam adagium politik, power tends to corrupt, absolute power corrupt absolutely. Dari pemikiran semacam inilah muncul ide pemisahan kekuasaan Negara ke dalam beberapa bagian. ${ }^{57}$ Singkatnya, wewenang besar yang

\footnotetext{
55 Pasal 107 ayat (3) dan (4) Dustûr al-Islâmy Hizbut Tahrir.

${ }^{56}$ Harold D. Laswell dan Abraham Kaplan mendefinisikan kekuasaan sebagai suatu hubungan di mana seseorang atau kelompok orang dapat menentukan tindakan seseorang atau kelompok lain ke arah tujuan dari pihak pertama. Miriam Budiardjo, Dasar-Dasar Ilmu Politik (Jakarta: Gramedia Pustaka Utama, 2008), hal. 60.

57 Pemisahan kekuasaan dalam negara pada umumnya direalisasikan melalui pembentukan beberapa alat kelengkapan Negara untuk menjalankan fungsi-fungsi tertentu. Pembentukan lembaga Negara merupakan manifestasi dari mekanisme keterwakilan rakyat dalam menyelenggarakan pemerintahan. Implementasi dari
} 
diberikan sistem pemerintahan Islam versi Hizbut Tahrir kepada seorang kepala negara rentan untuk disalahgunakan. Oleh karenanya, adopsi terhadap sistem pemerintahan modern dan modifikasi berkelanjutan merupakan suatu keniscayaan demi mencapai tujuan ideal dari sebuah 'pemerintahan Islam'.

\section{Daftar Pustaka}

Adhiatera, M. "Interfaith dialog: Agre to disagree" dalam The Jakarta Post, (Mei 2, 2006).

Amīruddin, M. Hasbi, Konsep Negara Islam Menurut Fazlur Rahman (Yogyakarta: UII Press, 2000).

Anonim. Afkâr Siyâsah. ttp: Hizbut Tahrir, 1994.

An-Nabhâni, Taqiyuddin, Mafâhîm Hizbut Tahrir, terj. Abdullah (Jakarta Selatan: Hizbut Tahrir Indonesia, 2001).

, Mafâhîm Siyāsah li Hizbit Tahrir, terj. M. Siddiq al-Jawi (Jakarta Selatan: Hizbut Tahrir Indonesia, 2007). , Al-Takatul al-Hizby, terj. Zakaria Labib, dkk. Jakarta Selatan: HTI Press, 2007). , al-Daulah al-Islâmiyyah, terj. Umar Faruq, dkk (Jakarta: HTI Press, 2009).

proses pemisahan kekuasaan dilakukan dengan membentuk organ-organ Negara yang memiliki kewenangan berbeda, tetapi saling berhubungan, sehingga dapat mencegah terjadinya dominasi satu cabang kekuasaan. Lihat Firmansyah Arifin, dkk, Lembaga Negara dan Sengketa Kewenangan Antarlembaga Negara (Jakarta: Konsorsium Reformasi Hukum Nasional, 2005), hal. 14-15. 
Daulah Islam, terj. Umar Faruq dkk. (Jakarta:

HTI-Press, 2009).

Arifin, Firmansyah, dkk., Lembaga Negara dan Sengketa Kewenangan Antarlembaga Negara (Jakarta:

Konsorsium Reformasi Hukum Nasional, 2005).

El Fadl, Khaled M. Aboe, Atas Nama Tuhan Dari Fikih Otoriter Ke Fikih Otoritatif (Jakarta: Serambi, 2004).

Firdaus, Robitul. 2010. "Pemisahan Kekuasaan dan Organisasi Negara dalam Sistem Pemerintahan Islam," Tesis (Yogyakarta: Pascasarjana UIN Sunan Kalijaga).

Kartono, Kartini, Pemimpin dan Kepemimpinan (Jakarta: PT. Raja Grafindo Persada, 1994).

Hizbut Tahrir. 2008. Struktur Negara Khilafah (Pemerintahan dan Administrasi), terj. Yahya A.R. Jakarta: HTI Press.

al-Maududi, Abul A'la, Hukum dan Konstitusi Sistem Politik Islam, terj. Asep Hikmat (Bandung: Mizan, 1990).

Al-Mawardi. t.t. Al-Ahkâm al-Sultoniyyah wa al-Wilayat alDiniyah. Beirut: Dar al-Kutub al-Ilmiyah.

Muhammad Bin Syakir Syarif. t.t. Muqaddimah fi Fiqh alNizāmi al-Islâmy. ttp: tp.

Pawito, Komunikasi Politik; Media Massa dan Kampanye Pemilihan. (Yogyakarta: Jalasutra, 2009).

Salim, Abdul Muin, Fiqh Siyasah; Konsepsi Kekuasaan Politik dalam Al-Quran. Jakarta: PT RajaGrafindo Persada, 2002).

Syadzali, Munawwir, Islam and Govermental System; Teaching, History, and Reflections (Jakarta: INIS, 1991).

Watt, William Montgomery, Fundamentalisme Islam dan Modernitas (Jakarta: PT RajaGrafindo, 1997). 